\title{
University volunteering. The UJI-Voluntària programme at the Universitat Jaume I
}

\author{
Lázaro Guillamón, C., García Renedo, M., \& Valero Valero, M. \\ Office for Development Cooperation and Solidarity (OCDS). \\ Universitat Jaume I (Castelló, Spain)
}

\begin{abstract}
Modern society encourages the development of values like solidarity, social commitment, altruistic actions and the establishment of social support networks. These values have been transferred to the university curriculum and students appear increasingly interested in carrying out volunteering activities. Specifically, the Universitat Jaume I in Castelló implements the UJI-Voluntària Programme, which has different areas of action aimed at offering members of the university community the chance to take an active part in achieving a fairer society and helping the people or groups in greatest need. We carried out a study for which we had a sample consisting of 62 students. We applied a Likert-type scale to analyse their satisfaction with the volunteering programme and their motivation for taking part in it. We found that the vast majority were women and second-year students. As for their motivation, the majority indicate their desire to help other people, followed by a desire to learn, and personal satisfaction. Finally, in relation to student satisfaction, the majority were satisfied with the running and development of the programme.
\end{abstract}

Keywords: Volunteering, university, motivation, programme, profile, solidarity

\section{Introduction}

Spanish universities are committed to transmitting values for the education of active, responsible citizens, committed to society. That makes volunteering a fundamental tool for bringing the university closer to society (Arias, 2008).

The aim of this paper is to present the way university volunteering is run at the Universitat Jaume I, via the UJI-Voluntària programme. In addition, the students' level of satisfaction with the programme will be presented, along with the profile of the gender and motivation for joining the programme of a typical volunteer.

\section{University volunteering}

Spanish universities began activities aimed at complying with their function as socially committed agents in society some years ago. As Arias (2008) pointed out: "A university can and must build attitudes, values and habits to be adopted as a way of life."

The Universities Act 6/2001, dated 21 December (BOE 24/12/2001), amended by Act 4/2007, dated 12 April, (BOE 13/04/2007), both in its preamble and its articles, establishes that "Universities will encourage the participation of members of the university community in international cooperation and solidarity activities and projects."

In order to unify and identify the lines of work carried out by universities concerning volunteering, the Conference of Rectors of Spanish Universities (CRUE) approved the document:

University: Social Commitment and Volunteering (2001). It describes the aims and lines of action by universities in support of volunteering activities. With the appearance of this document, universities were given a leading role in the promotion of volunteering and in putting strategies in place to allow them to contribute to building a fairer society through volunteering. 
We would like to make it clear, as Lázaro and Escribano (2009) have already highlighted, that universities are not Non-Governmental Organisations for Development (NGODs) or volunteer organisations. University volunteering has its own features which we will mention in the paper.

\section{The UJI-Voluntària programme at the Universitat Jaume I}

As a scientific and academic institution as well as a social agent, the Universitat Jaume I in Castelló is deeply interested in contributing to the development of the social sectors in greatest need and promoting committed, modern citizens. As part of assuming this responsibility, since 2010, the Universitat Jaume I has had the UJI-Voluntària programme. This programme is run by the Office for Cooperation for Development and Solidarity (OCDS) of the Office of the Vice-Rector for Internationalization, Cooperation and Multilingualism of the Universitat Jaume I. The programme is aimed at the whole university community (students, teaching and research staff and administrative and services staff). The aims pursued by the programme are:

- To involve the university community in social action activities.

- For the university to take part in achieving values that make society fairer.

- To highlight and teach the value of public participation.

- To stimulate reflection and critical thought about the problems affecting societies.

The following programmes are currently running:

- Helping students with special educational needs

- School support and integration

- Support for elderly and dependent people

- Volunteering at the Psychosocial Observatory of Resources in Disaster Situations (OPSIDE)

- Volunteering at the Permanent Observatory on Immigration (OPI-UJI)

- Volunteering in sport

- Environmental volunteering

- Showing the University programme

- Support to NGOs

- Language volunteering

- MENTOR programme

- Volunteering in Europe and other countries

- Volunteering for the prevention of violence

- Solidarity flats

- Ambassador programme

Each of these programmes includes different associations with which volunteers can volunteer.

\section{Operation of the programme}

To sign up and obtain information on the programme, the university community goes to the Office of Cooperation for Development and Solidarity (OCDS). The OCDS informs them about the existing programmes and they can consult a guide providing information including the description of all the programmes, the associations where they will do their volunteering and the activities they will carry out. If they are still interested, they fill in an application form. After this is analysed, and depending on their 
interests, the information is sent to the relevant association. The associations then contact the volunteers. When volunteers join, they sign an incorporation agreement and receive basic training (what it means to be a volunteer, rights, duties, etc.) given by the OCDS and specific training, which depends on the association. When the programme is complete, they are issued with certificates showing the hours they have worked and the equivalent credits for participation in solidarity activities. Before the certificate is presented, volunteers have to fill in an evaluation sheet.

\section{Volunteer satisfaction and profile}

In order to find out about the profile of the volunteers forming part of the UJIVoluntària programme and their level of satisfaction, we carried out a descriptive study, shown below.

\section{Sample}

The sample consists of 62 students on courses at the Universitat Jaume I in the academic year 2012-2013 who took part in the UJI-Voluntària Programme.

\section{Procedure}

At the end of the academic year, the students who took part in the programme filled in a questionnaire evaluating the experience. The questionnaire showed the students' personal details, their motivation for volunteering and their level of satisfaction with the programme. The evaluation scale was the Likert type (1 representing very unsatisfied and 5 completely satisfied).

\section{Data analysis}

The data was analysed descriptively using the SPSS (Statistical Package for Social Sciences) statistical program.

\section{Results}

Figure 1 shows results disaggregated by gender:

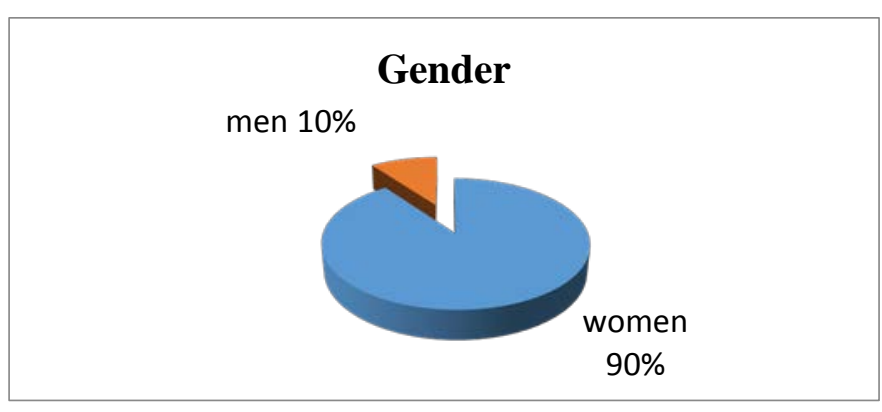

Figure 1. Gender of people participating in UJI-Voluntària

As shown in Figure 1, the vast majority of students who participate in UJI-Voluntària programme are women (90\%).

Figure 2 shows the specific academic year that is being attended by participant students. 


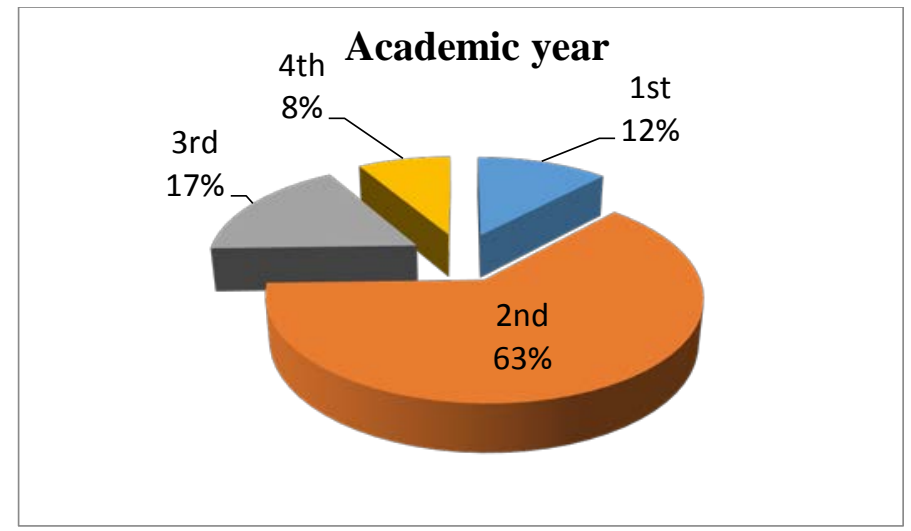

Figure 2. Students' academic year.

Most of the students who participated in UJI-Voluntària programme were attending 2nd year. Figure 3 shows the reasons that encourage students to undertake voluntary action.

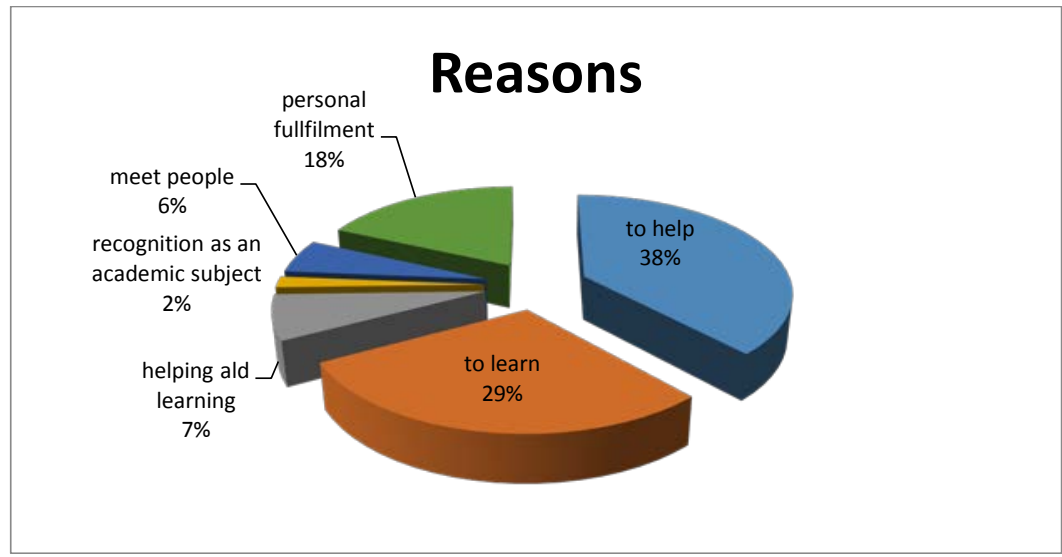

Figure 3. Students’ reasons to take part in UJI-Voluntària

With regard to the motivations/reasons the survey results stands out, as stated the study of Yubero and Larrañaga (2002), that the two main motivations/reasons that encourange students to take part of a university volunteer programme is helping and receive training, skills and abilities.

Finally, Figure 4 shows the assessment of UJI-Voluntària made by volunteers.

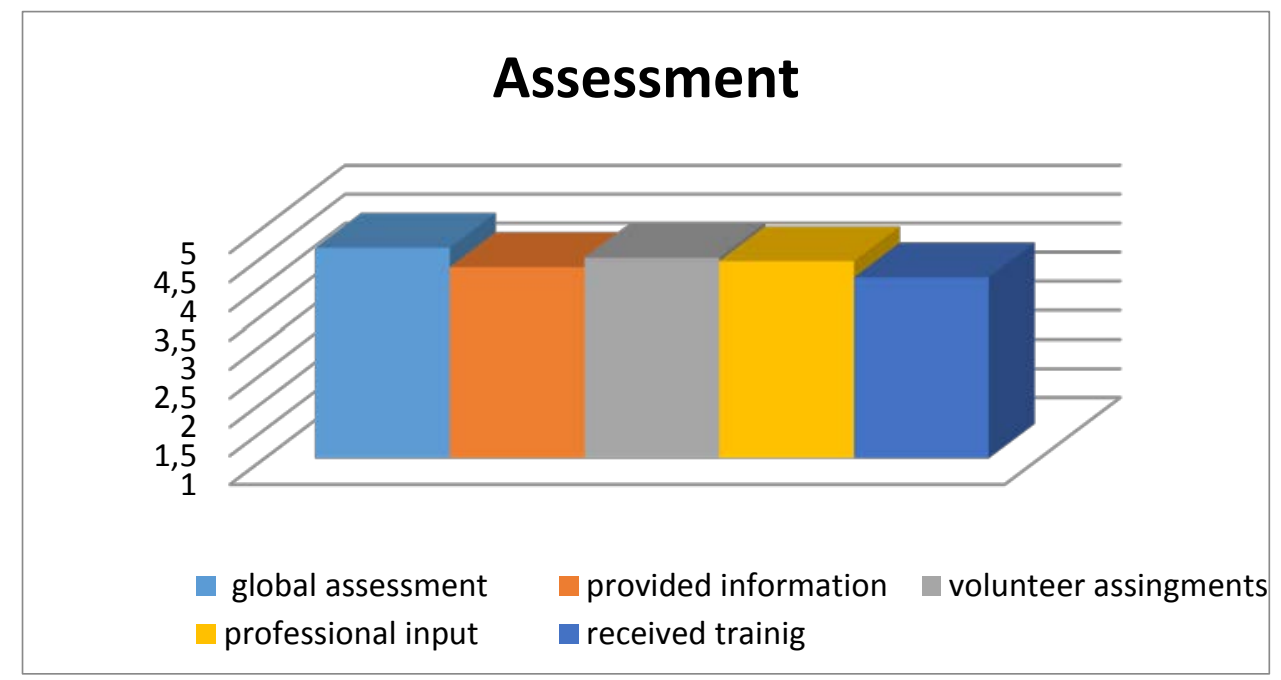

Figure 4. UJI-Voluntària assessment 
Broadly we found that students make a very positive assessment of the program. All ratings are above 4 . They are very satisfied with the training they have received, the information received, the contribution of the programme in the acquisition of professional knowledge and skills and the tasks that have been made as part of the volunteering program.

\section{Conclusions}

University volunteering is currently increasing and the sector is becoming stronger. At the Universitat Jaume I, as part of the UJI-Voluntària programme, we find that the profile of a typical volunteer corresponds to a female higher-level student.

The results of the study carried out on the motivation of students participating in UJIVoluntària show that the volunteers do provide disinterested help to other people, institutions and organizations because, although they can obtain optional credits for volunteering activity, the vast majority are largely motivated by a desire to help, followed by an interest in learning from the experience. This could result in better performance when students complete their studies and join the job market with a greater capacity for teamwork and cooperation.

At the same time, volunteering also allows students to confront and discover social problems different to their own, as well as other realities, other groups of the population and communities with diverse characteristics. This contributes towards the acceptance and development of tolerance towards other cultures, as well as the recognition of difference and personal dignity.

University volunteering contributes towards providing students with conflict resolution strategies and increased personal autonomy for solving problems.

As a result, students participating in voluntary activities also develop greater competence in social skills and they learn to take responsibility, putting other people's wishes and needs before their own, with which they acquire and maintain social commitment.

Ultimately, university volunteering brings the university as an institution closer to society and improves its involvement in the community. It also contributes to the complete education of people and promotes the awareness of participatory citizenship that will contribute to strengthening the social fabric through the transformative social action of university volunteers.

\section{References}

Arias, S (2008). Voluntariado Universitario. Guía para su gestión en las universidades madrileñas. Madrid: Dirección General de Voluntariado y Promoción Social.

CRUE (2000). Estrategia de Cooperación Universitaria al Desarrollo.

CRUE (2001). Universidad: Compromiso Social y Voluntariado.

CRUE (2006). Código de Conducta de las universidades españolas en materia de cooperación al desarrollo.

CRUE (2006). Protocolo de actuación de las universidades frente a situaciones de crisis humanitarias. 
Lázaro, C y Escribano, P (2009). Training for University Volunteers. A step foward in higher education for development. Proceedings of EDULARSN09 Conference. $6^{\text {th }}$ $8^{\text {th }}$ July, 2009. Bacelona: Spain.

Ley Orgánica 4/2007, de 12 de abril, por la que se modifica la Ley Orgánica 6/2001, de 21 de diciembre, de Universidades. (B.O.E. 13/04/2007)

Ley Orgánica 6/2001, de 21 de diciembre, de Universidades (BOE. 24/12/2001)

Ley 6/1996, de 15 de enero, de voluntariado. (BOE de 17/01/1996)

Real Decreto 1393/2007, de 29 de octubre, por el que se establece la ordenación de las enseñanzas universitarias oficiales. (BOE 30/10/2007).

Yubero, S y Llarrañaga, E. (2002). Concepción del voluntariado desde la perspectiva motivacional: conducta de ayuda \& altruismo. Pedagogía Social. Revista Interuniversitaria, 9, 27-39. 